\title{
KEANGGOTAAN VIETNAM DALAM PENANGANAN RANJAU DARAT ANTI-PERSONIL (RDAP) DAN EXPLOSIVE REMNANTS OF WAR (ERW) MELALUI ASEAN REGIONAL MINE ACTION CENTER (ARMAC)
}

\author{
Maulida Fitriyanti ${ }^{1}$ \\ ${ }^{1}$ Departemen Hubungan Internasional Fakultas Ilmu Sosial \& Ilmu Politik \\ Universitas Indonesia \\ maulidafitriyanti@gmail.com
}

\begin{abstract}
The presence of landmines and explosive remnants of war (ERW) is considered a global issue. Landmines and ERW are seen as humanitarian threat since it affect people's safety. The need for international regime to solve the issue is pivotal for this paper. ASEAN Regional Mine Action Center (ARMAC) as the regime to address the issue in Southeast Asia has important roles. Vietnam as one of ASEAN countries which heavily affected by the war has left its legacy of landmines and $E R W$. Since landmines and ERW in Vietnam were located in some civilian places, its danger has been quite alarming. Therefore, this paper discusses the participation of Vietnam as ARMAC member in resolving the issue of landmines and ERW. ARMAC is considered to be not as optimum as it should in resolving landmines and ERW issue in Vietnam. This result can be caused by the internal interest that Vietnam has.
\end{abstract}

Keywords: ASEAN Regional Mine Action Center (ARMAC), Vietnam, International regime

\section{PENDAHULUAN}

Perang yang terjadi di dunia telah menimbulkan dampak yang sangat luar biasa bagi negara-negara terlibat. Salah satunya ialah dampak yang ditimbulkan pada Perang Vietnam, yakni adanya sisa Ranjau Darat AntiPersonil (RDAP) dan juga Explosive Remnants of War (ERW) yang telah tertanam di wilayah Vietnam, namun tidak meledak pada saat terjadinya perang. Kehadiran senjata sisa perang tersebut dinilai sangatlah membahayakan keamanan negara dan masyarakatnya. Berdasarkan International Campaign to Ban Landmines (ICBL, 2006), dampak dari ranjau darat tidak hanya membunuh 
dan melukai warga sekitar, namun keberadaannya juga merusak lingkungan. Tanah-tanah yang tertanam ranjau tidak bisa digunakan sebagai lahan pertanian atau tempat tinggal karena sebelum lahan tersebut dinyatakan benarbenar bersih dan bebas dari ranjau darat yang masih tertanam dan aktif, penduduk setempat sama sekali dilarang untuk mendekati area itu untuk menghindari jatuhnya korban yang lebih banyak. Beberapa negara juga dianggap dengan sengaja memproduksi RDAP tersebut. Berdasarkan laporan ICBL tahun 2006, terdapat 13 negara yakni Burma, Cina, Cuba, India, Iran, Korea Utara, Korea Selatan, Nepal, Pakistan, Rusia, Singapura, Amerika Serikat, dan Vietnam. Namun, dari 13 negara yang disinyalir memproduksi RDAP tersebut, terdapat beberapa negara yang tidak secara aktif melakukan produksi, diantaranya ialah Vietnam. Pada tahun 2005, beberapa pejabat Vietnam telah menyatakan bahwa Vietnam tidak lagi memproduksi RDAP (ICBL, 2006).

Berdasarkan pernyataan di atas, beberapa negara yang wilayahnya diyakini mengandung RDAP dan ERW adalah negara-negara di Asia Tenggara. Dalam sejarah singkat adanya RDAP dan ERW di Asia Tenggara, Kamboja dan Vietnam menjadi dua negara yang dinilai paling banyak memiliki RDAP dan ERW lantaran dampak perang yang terjadi beberapa puluh tahun yang lalu. Sehingga hal tersebut menggerakkan inisiasi bagi ASEAN, selaku institusi regional di Asia Tenggara untuk membentuk suatu wadah guna menangani permasalahan RDAP dan ERW tersebut. Tahun 2012, pada Cambodia's ASEAN Chairmanship, Perdana Menteri Kamboja mengusulkan pembentukan wadah penanggulangan RDAP dan ERW tersebut. Lalu terbentuknya apa yang dinamakan ASEAN Regional Mine Action Center (ARMAC) pada 2013. ASEAN Regional Mine Action Center (ARMAC) merupakan framework bagi negara-negara anggota ASEAN terkait penanganan ranjau darat dan Explosive Remnants of War (ERW) secara kolektif. Pertemuan ARMAC yang pertama terjadi pada tahun 2016 guna meresmikan operasionalisasi fungsi ARMAC tersebut (ASEAN, 2016).

Kamboja dan Vietnam sebagai dua negara di Asia Tenggara yang mendapat dampak langsung dengan adanya senjata sisa perang tersebut juga seharusnya 
merasakan hasil dari dibentuknya ARMAC tersebut. Namun begitu, peran ARMAC bagi kedua negara tersebut nampak sangat berbeda. Jika melihat data dari Kamboja terkait korban RDAP dan ERW pada tahun 2015 sebanyak 111 korban jiwa menurun dari tahun sebelumnya yakni sebanyak 154 korban jiwa dan juga korban pada tahun 2017 sebanyak 58 menurun dari tahun sebelumnya sebanyak 83 korban jiwa (Landmine Cluster Monitor, 2016). Sedangkan di Vietnam justru mengalami peningkatan yakni dari 7 di tahun 2015, 9 di tahun 2016, menjadi 14 di tahun 2017 (Landmine Cluster Monitor, 2018). Meskipun 3 tahun sebelum tahun 2015, telah terjadi penurunan yang drastis, namun begitu semenjak 2015-2017 terjadi kembali peningkatan. Padahal mengingat tahun 2017 telah satu tahun ARMAC diresmikan dengan segala fungsi dan operasionalisasinya. Sejak tahun 1975 hingga 2017 di Vietnam telah tercatat sebanyak 105.073 korban ERW, 38.978 korban meninggal dunia, dan 66.093 korban luka-luka, serta 2 tidak diketahui. Melihat data tersebut, meskipun jumlah korban di Kamboja lebih banyak daripada Vietnam, namun fluktuasi peningkatan dan penurunan jumlah menjadi faktor utama dalam penentuan objek penelitian tulisan ini. Dapat dikatakan bahwa peran ARMAC bagi Kamboja sudah terlihat, namun belum bagi Vietnam.

Berdasarkan data dari Landmine \& Cluster Monitor, Vietnam termasuk negara dengan luas wilayah $61.304 \mathrm{~km}^{2}$ terkontaminasi oleh ERW. Beberapa wilayah terkontaminasi juga berada di wilayah-wilayah sentral, seperti central coastal, central highland, delta sungai Mekong, dan juga delta sungai Merah. Lantaran beberapa letaknya yang di pusat area menjadikan RDAP dan ERW sangat berbahaya bagi keselamatan masyarakat setempat. Oleh sebab itu, ASEAN diharapkan dapat menunjukkan peranan yang baik dalam melindungi hak-hak hidup seluruh masyarakat ASEAN (Alkadrie Mooy, 2016). Salah satu upaya perlindungan masyarakat ASEAN ditunjukkan dengan melakukan peningkatkan kesadaran bahaya RDAP dan ERW. Upaya tersebut termasuk ke dalam tujuan utama ARMAC, namun sepertinya belum dilaksanakan secara efektif oleh Vietnam. 
Beberapa kajian akademis terdahulu terkait permasalahan RDAP dan ERW dan efek bahayanya cenderung fokus pada: (1) kesehatan; (2) kesepakatan antar negara, dan; (3) politik, sosial, ekonomi. Kategori kajian pertama membahas mengenai bahaya RDAP dan ERW terhadap kesehatan manusia. RDAP dan ERW dianggap mengancam keamanan insani. Permasalahan RDAP dan ERW yang memakan korban jiwa dianggap tidak hanya mengancam secara fisik tetapi juga ada ancaman psikologis secara langsung terhadap masyarakat yang terlibat (Frost, et al, 201). Selain itu, luka bahkan kematian yang diakibatkan oleh RDAP dan ERW tetaplah menjadi momok bukan hanya bagi masyarakat biasa namun juga bagi para tentara yang berperang. Tidak hanya itu, penanganan terhadap luka yang diakibatkan oleh senjata tersebut juga membutuhkan prosedur yang tidak sembarangan (Trimble \& Clasper, 2001).

Kajian kategori kedua berfokus pada adanya kesepakatan antarnegara dalam menangani permasalahan RDAP dan ERW tersebut. Salah satu kesepakatan internasional yang terjadi antarnegara tertuang dalam Konvensi Ottawa. Dalam sebuah konvensi, keberhasilan maupun kegagalannya sangatlah berkaitan dengan negara-negara anggota mengambil alih implementasi (Brinket, 2003). Selain itu, terdapat pula kesepakatan antarnegara yang terjadi di dalam sebuah Non-Governmental Organization (NGO). Kesepakatan yang terjadi lantaran mereka mempunyai tujuan yang sama yakni mendukung pemusnahan RDAP dan ERW. Kesepakatan yang terjalin menjadikan adanya global mine-ban movement yang mempunyai tujuan untuk mempengaruhi media dan teknologi lainnya guna menyebarkan statistik tidak tetap, gambar, dan lain-lain yang memicu negara untuk melakukan tindakan lantaran adanya tekanan dari berbagai pihak (Matthew \& Rutherford, 2003). Tidak hanya dengan kesepakatan yang mengikat, namun terdapat juga NGO yang didalamnya diikuti oleh beberapa negara. NGO juga berfungsi dalam melakukan pembelajaran sosial secara langsung terhadap apa yang disebut dengan mine action. Aktivitas yang dijalankan oleh NGO dalam melakukan pendekatan terhadap penanganan RDAP dan ERW juga mendorong terhadap munculnya community. Hal tersebut 
lantaran NGO bekerja sama dengan yang lainnya dalam mencapai tujuannya (Gilson, 2009).

Kajian kategori terakhir berfokus terhadap politik, sosial, ekonomi. Dalam kategori ini, terdapat pasar yang mewadahi RDAP dan ERW. Tidak hanya itu, berdasarkan penelitian yang dilakukan di Kamboja, kepentingan politik juga dianggap telah mempengaruhi distribusi maupun penanganan RDAP dan ERW (Chapman, 2010). Selain itu, adanya RDAP dan ERW juga dilihat sebagai bentuk krisis ekonomi-sosial. Hal tersebut disebabkan lantaran adanya dampak kesehatan yang akan berujung pada finansial dalam menangani masalah kesehatan tersebut. Oleh karena itu, secara tidak langsung dampak yang ditimbulkan oleh RDAP dan ERW juga merambah pada sosial-ekonomi (Williams, 1995).

Ketiga kategori tersebut membahas secara umum mengenai permasalahan RDAP dan ERW. Dilihat dari kategori kedua, kesuksesan sebuah framework internasional juga dilandasi pada adanya rasa kepemilikan implementasi yang diterapkan oleh tiap negara anggota yang telah menyetujui framework tersebut. Pembahasan mengenai satu negara secara spesifik juga belum terlalu muncul pada kajian terdahulu, hanya negara Kamboja yang sempat menjadi objek penelitian dalam kajian terdahulu. Secara khusus, kajian-kajian terdahulu belum membahas mengenai spesifik mengenai tingkat efektivitas framework regional, yakni ARMAC terhadap keanggotaan Vietnam. Oleh karena itu, tulisan ini mengangkat pertanyaan, "Mengapa setelah dibentuknya ARMAC, masalah RDAP dan ERW di Vietnam masih mengalami peningkatan meskipun kegiatan-kegiatan penanganan masalah tersebut telah ada?" Teori rezim internasional akan digunakan untuk menganalisa permasalahan pada penelitian ini. Pada bagian selanjutnya akan dijelaskan deskripsi teori yang digunakan untuk analisa.

Teori rezim berbicara bagaimana ketaatan negara anggota terhadap suatu rezim internasional dalam mewujudkan kepentingan mereka. Dalam hal ini, ARMAC berfungsi sebagai rezim di kawasan memiliki peran untuk menangani permasalahan RDAP dan ERW yang terdapat di negara-negara anggotanya. 
Menurut Puchala dan Hopkins (1982), rezim selalu ada di setiap isu area hubungan internasional lantaran terdapat keteraturan perilaku seperti prinsipprinsip, norma-norma, atau aturan-aturan yang harus ada untuk dipertanggungjawabkan. Menurut Oran R. Young (1980), rezim merupakan institusi sosial yang mengatur tindakan anggotanya yang tertarik pada sebuah aktivitas yang spesifik (atau serangkaian kegiatan yang bermakna) di dalam komunitasnya, rezim juga merupakan sebuah struktur sosial. Puchala dan Hopkins (dalam Haggard and Simmons), teori rezim internasional merupakan pendekatan yang mengasumsikan bahwa perilaku sebuah negara dipengaruhi oleh adanya norma dalam sistem internasional. Dikatakan bahwa norma ini terdapat dalam area isu dalam sistem internasional (Haggard \& Simmons, 1987). Rezim dianggap lemah tanpa adanya koherensi dari prinsip, norma, aturan, dan prosedur pengambilan keputusan (Krasner, 1982).

Sementara itu Hasenclever et. al. (2000), berdasarkan teori Rezim Internasional yang berasal dari tradisi liberal, berargumen bahwa berbagai institusi atau rezim internasional mempengaruhi perilaku negara-negara maupun aktor internasional yang lain. Sebuah rezim diorganisasikan dengan perjanjian antarnegara, sehingga dapat menjadi sumber utama hukum internasional. Lebih jauh lagi rezim dapat membentuk perilaku dari negaranegara penyusunnya.

Selain itu, Hasenclever et. al., juga secara spesifik membagi pendekatan mengenai rezim internasional kedalam, teori berdasarkan kepentingan (interestbased theory) dan teori berdasarkan kekuatan (power-based theory). Pendekatan interest-based theory erat kaitannya dengan paradigma neoliberalis yang memiliki asumsi bahwa adanya rezim internasional akan dapat membantu negara-negara untuk merealisasikan kepentingannya. Interest-based kemudian dikategorikan menjadi dua fokus, yakni kontraktualisme dan strukturalismesituasi. Sedangkan pendekatan power-based theory sangat dekat dengan paradigma realis yang berasumsi bahwa kebutuhan negara juga merupakan relative gains, sehingga kerja sama antarnegara perlu untuk dikaji ulang. 
Meskipun realis tidak terlalu melihat institusi internasional dalam pembahasannya, namun tidak dipungkiri bahwa kerja sama berbasis rezim tetap dibutuhkan guna pemenuhan public goods.

\section{PEMBAHASAN}

\section{Kontraktualisme dalam Pembentukan ASEAN Regional Mine Action Center (ARMAC) sebagai Rezim Internasional}

Sebagian besar negara-negara di kawasan Asia Tenggara, termasuk Kamboja, Thailand, Laos, Myanmar, Filipina, Vietnam, merupakan wilayah yang terkena dampak perang terlihat dari adanya sisa-sisa RDAP dan ERW (Akbe, 2019). Adanya senjata-senjata sisa perang yang terkubur di dalam tanah tersebut sangatlah berbahaya bagi masyarakat. Senjata-senjata sisa perang yang tidak meledak pada saat perang tersebut, masih bersifat aktif sehingga dapat memakan korban jiwa.

Banyaknya korban jiwa yang jatuh lantaran adanya RDAP dan ERW yang dengan tidak sengaja meledak telah membuat negara-negara ASEAN menjadi lebih sadar akan pentingnya penanggulangan yang segera terkait masalah tersebut. Berdasarkan data dari Landmine \& Cluster Munition (2016), di Kamboja sendiri sebanyak 64.579 korban jiwa terhitung sejak tahun 1979 diakibatkan oleh RDAP dan ERW. Sementara itu di Vietnam, hampir dua kali lipat, yakni sebanyak 105.073 korban jiwa terhitung sejak tahun 1975. Banyaknya korban yang muncul menjadikan RDAP dan ERW sangatlah berbahaya, apalagi keberadaan mereka yang tertanam di bawah tanah dan tidak secara langsung dapat terdeteksi.

Selain itu, kebanyakan dari korban ledakan RDAP dan ERW tersebut adalah masyarakat sipil dan juga anak-anak (Guillermo, 2019). Oleh karena itu, banyak negara-negara di dunia melihat hal ini sebagai masalah global yang harus diselesaikan demi misi kemanusiaan. Hal ini juga memacu negara-negara di Asia Tenggara untuk mulai memikirkan penyelesaian mengenai masalah tersebut. ASEAN sebagai institusi regional mulai memunculkan pembicaraan mengenai RDAP dan ERW dalam pertemuan-pertemuan resminya. 
Lantaran banyaknya anggota negara ASEAN yang terkena dampak adanya RDAP dan ERW tersebut akhirnya memunculkan adanya kepentingan bersama untuk menangani permasalahan tersebut. Dengan begitu, pada tahun 2012, Kamboja menginisiasi program bersama dalam penanganan RDAP dan ERW di kawasan Asia Tenggara. Pada tahun itu pula dalam ASEAN Summit Meeting yang ke-21 yang diadakan pada 18 November 2012, petinggi-petinggi negara anggota ASEAN mengadopsi pembentukan ASEAN Regional Mine Action Center (ARMAC). Setelah mendapat dukungan dari anggota negara ASEAN lainnya, akhirnya pada tahun 2013, Terms of Reference (ToR) dari ARMAC mulai disahkan pada ASEAN Summit Meeting ke-22. Dan menyetujui Kamboja sebagai Host Country dari ARMAC. Tahun 2014, gedung utama ARMAC mulai dibangun di Kamboja. Pembangunan sendiri berjalan selama dua tahun. Pada tahun 2016, gedung utama ARMAC akhirnya diresmikan. Pada tahun yang sama juga, Steering Committee Meeting yang pertama diadakan.

Lantaran ARMAC dibentuk di bawah payung ASEAN, maka semua negara ASEAN diharuskan untuk turut serta dalam kegiatan-kegiatan yang dilakukan oleh ARMAC. Pembentukan ARMAC yang juga didasari lantaran adanya common interest yang dimiliki ASEAN sebagai institusi kawasan juga menjadikan negara anggotanya secara otomatis terlibat, baik secara aktif maupun tidak. Setelah terbentuknya ARMAC, ASEAN yang notabene menganut prinsip non intervensi juga tidak serta merta dapat memaksa negara anggotanya untuk melakukan hal-hal tertentu secara paksa. Oleh karena itu, ARMAC menerapkan pendekatan guna mengatasi permasalahan RDAP dan ERW secara tidak langsung yakni dengan meningkatkan kesadaran semua negara anggota bahkan masyarakat terkait bahaya dari RDAP dan ERW. Selain itu, pendekatan lainnya dilakukan dengan memberikan fasilitas medis dan rehabilitasi jika ada negara anggota ASEAN yang memintanya. Terakhir, memberikan bantuan kepada negara anggota ASEAN yang tertarik untuk melakukan penelitian dalam hal RDAP dan ERW. Bantuan berupa finansial juga akan disediakan oleh ARMAC jika ada negara anggota ASEAN yang membutuhkan bantuan. 
Jika dilihat dari awal terbentuknya ARMAC menunjukkan adanya kesadaran yang mulai dimiliki oleh para negara anggota. Hal tersebut menjadi bukti adanya kesamaan kepentingan yang kemudian mewujudkan terbentuknya program-program yang harus dijalankan guna mengatasi permasalahan tersebut. Dengan terbentuknya ARMAC, maka negara-negara ASEAN mempunyai guidelines dalam menyikapi permasalahan RDAP dan ERW di kawasan. Oleh karena itu, pembentukan ARMAC dapat dilihat sebagai langkah penting yang telah diambil ASEAN dalam menyikapi permasalahan RDAP dan ERW.

Adanya kesamaan kepentingan negara-negara ASEAN, menjadikan adanya kontraktualisme dalam terbentuknya ARMAC. ARMAC juga memiliki legal instrument seperti Piagam ASEAN, ASEAN Political Security Blueprint 2025, ASEAN Leaders Statement on ARMAC, dan Terms of Reference of ARMAC, instrument legat tersebut tidak mengikat secara paksa seperti karakter ASEAN sendiri yang memang tidak terlalu formal. Lantaran berbasis pada prinsip dasar ASEAN, maka ARMAC tidak dapat memaksakan program kerjanya kepada semua negara anggota ASEAN. Hal ini juga dikarenakan adanya kepentingan domestik masing-masing negara yang menghalangi ARMAC dapat berjalan secara efektif dan optimal.

Banyak negara-negara ASEAN yang masih mengedepankan isu-isu lainnya seperti isu kesenjangan ekonomi, permasalahan politik masing-masing negara yang kompleks, serta isu-isu domestik lainnya yang dianggap lebih darurat. Oleh karena itu, banyak negara ASEAN yang harus mengedepankan agenda untuk menyelesaikan permasalahan-permasalahan domestik terlebih dahulu (Heng, 2020). Hal ini dapat menjadikan alasan kurang optimalnya ARMAC. Tidak hanya permasalahan domestik yang menjadi isu darurat, namun permasalahan batas kawasan juga masih menjadi bahan diskusi hangat bagi negara-negara ASEAN.

Permasalahan-permasalahan tersebut juga dihadapi Vietnam yang notabene negara ASEAN dengan jumlah RDAP dan ERW yang besar yakni sekitar 3 juta unit masih terkubur dalam tanah di wilayah Vietnam (Rogers \& 
Kuhn, 2017). Meskipun memiliki jumlah wilayah luas yang terkena dampak RDAP dan ERW, Vietnam juga menghadapi permasalahan isu sosial domestik yang menuntut penyelesaian. Lantaran negara memiliki sifat rasionalis, oleh karena itu, Vietnam masih memilih untuk mengedepankan isu-isu domestik darurat dan adanya tuntutan dari masyarakat untuk segera diselesaikan sehingga program-program ARMAC belum sepenuhnya optimal bagi Vietnam dalam menangani permasalahan RDAP dan ERW.

\section{Strukturalisme-Situasi dalam Pembentukan ASEAN Regional Mine Action Center (ARMAC) sebagai Rezim Internasional}

Strukturalisme-situasi merupakan penjabaran yang lebih luas dan mendalam dari kontraktualisme (Hasenclever, et. al., 1996). Bagaimana rezim dibentuk, dijalankan, dikembangkan, dan dijaga merupakan fokus yang ada dalam strukturalisme-situasi. Dalam hal ini, koordinasi dan kolaborasi bersama dalam rezim internasional dianggap perlu untuk dilakukan anggota-anggota rezim (Hasenclever, et. al, 1996). Namun begitu, lantaran sifat dasar dari kedua proses tersebut yang berbeda, sehingga diharapkan hasil yang didapatkan akan berbeda pula.

Perang-perang yang terjadi di Asia Tenggara telah berakhir hampir 50 tahun yang lalu, namun dampaknya dari segi humanitarian masih terasa hingga saat ini. Negara-negara seperti Laos, Kamboja, Vietnam masih merasakan bahayanya setiap hari lantaran adanya senjata sisa perang yang tertanam dalam tanah dan belum meledak. Permasalahan ini semakin menjadi kekhawatiran negara-negara ASEAN yang sebagian besar memiliki wilayah dengan RDAP dan ERW hingga puluhan hektar. Oleh karena itu, upaya bersama dalam penyelesaian permasalahan tersebut dijadikan sebagai landasan dalam mendirikan adanya rezim kawasan.

Setelah melalui berbagai proses, akhirnya ASEAN Regional Mine Action Center (ARMAC) dibentuk. Meskipun beberapa negara anggota ASEAN lainnya tidak terkena dampak humanitarian dari RDAP dan ERW, adanya solidaritas dalam institusi menjadikan terbentuknya ARMAC mendapat dorongan dan 
dukungan dari negara-negara anggota. Dengan persentase wilayah terkena dampak RDAP dan ERW yang cukup besar, menjadikan isu tersebut menjadi permasalahan yang patut mendapat perhatian kawasan. Di era sekarang ini, isu kemanusiaan menjadi salah satu fokus utama dalam menjalankan sebuah rezim. Oleh karena itu, demi mengatasi jatuhnya korban yang semakin banyak akibat RDAP dan ERW, maka ASEAN berkolaborasi bersama untuk menjadikan ARMAC sebagai wadah untuk bersama-sama mencari jalan keluar terbaik dalam penyelesaian permasalahan tersebut.

Dalam upaya untuk menyelesaikan permasalahan RDAP dan ERW di kawasan Asia Tenggara, ARMAC sendiri telah mengadakan partnership dengan berbagai organisasi maupun negara-negara lain untuk mendapatkan bantuan. Berdasarkan data dari ARMAC Annual Report tahun 2020, terdapat lebih dari 40 pihak yang terlibat dalam kerjasama dengan ARMAC. Pihak-pihak tersebut tidak hanya terdiri dari negara-negara non ASEAN, tetapi juga dari organisasiorganisasi non-governmental. Beberapa negara-negara yang terlibat dengan program ARMAC diantaranya ialah, Amerika Serikat, Tiongkok, Australia, Swiss, Swedia, UK, Turki, Italia, Rusia, dan lainnya. Beberapa NGO internasional juga turut ikut serta dalam kerjasama ARMAC antara lain, APOPO, HALO Trust, Mine Advisory Group (MAG), dan masih banyak lainnya. Selain mendapat dukungan dari luar, beberapa organisasi dalam kawasan seperti Cambodian Mine Action and Victim Assistance Authority (CMAA), Cambodian Mine Action Center (CMAC), Myanmar MSWRR, NPMEC, NRA Lao PDR, TMAC, UXO Lao, VNMAC.

Adanya berbagai macam kerja sama dengan pihak-pihak internasional lainnya menandakan bahwa permasalahan RDAP dan ERW haruslah ditangani secara serius. Kerjasama-kerjasama yang terjalin tersebut secara kolektif menjadikan ARMAC sebagai instrumen dalam menyelesaikan permasalahan RDAP dan ERW di kawasan Asia Tenggara. Adanya berbagai perjanjian dan kerja sama menunjukkan keseriusan ARMAC dalam menjalankan program kerjanya agar dapat menumbuhkan awareness bagi masyarakat ASEAN secara 
keseluruhan untuk bersedia turun bersama dalam menyelesaikan permasalahan kemanusian yang diakibatkan oleh RDAP dan ERW tersebut.

Selain menjalin kerja sama dengan pihak-pihak internasional, ARMAC juga secara rutin mengadakan pertemuan komite dalam membahas perkembangan permasalahan RDAP dan ERW di kawasan Asia Tenggara. Situasi krisis kemanusiaan akibat masalah ranjau menjadikan ARMAC untuk semakin gencar menjalankan program kerjanya tersebut. Meskipun ARMAC telah menyusun program kerjanya serta menjalin kerja sama internasional, permasalahan RDAP dan ERW juga harus mendapat persetujuan dari negaranegara terlibat. Dalam hal ini, jika ARMAC dengan NGO bekerjasama untuk melakukan training, namun negara yang seharusnya menjadi peserta training tidak menunjukkan persetujuannya maka terhambatlah program ARMAC tersebut.

Dengan adanya prinsip non-intervensi ASEAN, maka tidak ada yang bisa memaksakan negara anggota lainnya untuk turut serta dalam program kerja ARMAC maupun dalam kerjasama-kerjasama yang telah dibangun oleh ARMAC. Hal inilah yang kemudian dapat menjadi batu sandungan dalam penyelesaian permasalahan secara kolektif. Dalam menjalankan programnya, koordinasi antar anggota sangatlah diperlukan. Namun, koordinasi ini tidak begitu saja dengan mudah didapatkan. Lantaran negara-negara ASEAN sangatlah beragam sehingga situasi yang dihadapi pun berbeda-beda. Perbedaan itu tidak serta merta dapat diselesaikan dengan mudah. Adanya boundary yang harus dijaga menjadikan koordinasi antarnegara menjadi lebih kompleks. Secara teknis, upaya untuk mengurangi banyaknya jumlah wilayah yang terkena dampak RDAP dan ERW dilakukan dengan proses demining. Proses tersebut tidaklah dapat dilakukan dengan mudah, karena banyak alat dan juga skill tertentu yang diperlukan.

Oleh karena itu, salah satu kegiatan ARMAC yang terkesan lebih sederhana adalah dengan adanya pertemuan-pertemuan maupun seminar untuk mengajak masyarakat ASEAN lebih peduli terhadap isu RDAP dan ERW. Selain itu, di ASEAN sendiri isu kemanusian lainnya seperti isu Rohingnya 
masih menjadi fokus yang lebih utama dan darurat jika dibandingkan dengan isu kemanusiaan akibat RDAP dan ERW. Lantaran kondisi situasi yang berbeda-beda dihadapi oleh negara-negara ASEAN, maka pengaruh peran ARMAC pun berbeda pula. Di Kamboja sendiri isu RDAP dan ERW sangatlah diutamakan sehingga banyak program kerja yang dilakukan untuk mencapai penyelesaian.

Hal ini nampaknya berbeda dengan Vietnam, lantaran kondisi ketimpangan perekonomian yang sangatlah buruk menjadikan isu ini untuk diutamakan. Berdasarkan data statistik, pendapatan warga miskin semakin menurun dari tahun ke tahun, $18 \%$ di 2002, 15\% di 2010, 14,9\% di 2012, hingga $14,6 \%$ di 2018 , sehingga isu ketimpangan menjadi sangatlah dominan (Pham \& Riedel, 2019). Isu kesenjangan perekonomian di Vietnam telah menjadi topik hangat sejak beberapa dekade lamanya. Lantaran situasi yang dihadapi Vietnam tersebut, maka keaktifan partisipasi Vietnam dalam ARMAC masih belum optimal. Hal inilah yang menjadi salah satu alasan kurang efektifnya ARMAC bagi Vietnam dalam menangani isu RDAP dan ERW.

\section{Pemenuhan Public Goods Vietnam melalui ASEAN Regional Mine Action Center (ARMAC)}

Dalam konstruksi pembentukan rezim internasional yang menggabungkan power dan interest memunculkan adanya partisipasi baik yang aktif maupun yang tidak aktif dari para anggotanya sebagai hal yang wajar. Hal ini dipicu oleh adanya sifat rasional negara yang memikirkan pemenuhan kebutuhannya terlebih dahulu. Oleh karena itu, peran aktor dominan dalam sebuah rezim hendaknya diperlukan guna mendorong anggota lainnya agar dapat berperan aktif dan mendapatkan pemenuhan public goods dari adanya rezim tersebut.

Dalam isu permasalahan RDAP dan ERW, public goods yang dimaksudkan dapat berupa perlindungan terhadap warga negara atas bahaya yang dapat ditimbulkan oleh adanya amunisi-amunisi sisa perang tersebut. Salah satu upaya untuk pemenuhan public goods tersebut adalah dengan membentuk 
kerjasama kawasan yakni berupa ARMAC. Tujuan bersama yang dimiliki oleh ARMAC telah dirasa mewakili keinginan negara anggota untuk menyediakan public goods bagi warga negaranya.

Sebagai rezim yang berada dibawah prinsip dasar payung ASEAN, maka wajar jika dalam ARMAC tidak terdapat salah satu aktor yang bertindak dominan untuk dapat mendorong anggota negara lainnya. Lantaran sifat seluruh anggota negara yang sama dan tidak melebihi lainnya, maka tidak ada aktor yang dapat menjadi pendorong anggota lainnya untuk mengikuti seluruh kegiatan maupun program kerja yang dijalankan oleh ARMAC. Hal ini dapat dilihat sebagai tidak adanya power dalam hubungan antarnegara anggota. Oleh sebab itu, anggota tidak dapat dipaksakan untuk turut berperan aktif dalam rezim tersebut.

Dengan melihat kondisi kawasan tersebut, maka pemenuhan terhadap public goods tidak dapat dicapai dengan mudah. Hal ini yang kemudian memicu kurang efektifnya rezim bagi anggotanya. Terkait dengan isu RDAP dan ERW, banyak hal yang perlu diperhatikan untuk menangani permasalahan tersebut. ARMAC sendiri telah melakukan kerja sama dengan berbagai pihak untuk mendorong tercapainya public goods yang diharapkan oleh negara anggota. Public goods yang diharapkan didapat dari ARMAC sendiri tidaklah dengan mudah dapat terpenuhi. Upaya untuk memberikan perlindungan terhadap warga negara dari bahaya senjata sisa perang yakni dengan melakukan proses demining. Namun dalam upaya untuk menjalankan proses demining banyak faktor yang harus dipertimbangkan.

Proses tersebut butuh pelatihan kepada individu yang akan terjun langsung ke lokasi dimana RDAP dan ERW berada. Meskipun alternatif lainnya telah dikembangkan untuk melakukan proses demining. Salah satunya adalah dengan melatih tikus untuk dapat mendeteksi letak sisa senjata perang tersebut. Namun begitu, proses pelatihan tikus tersebut dapat memakan waktu hingga delapan bulan lamanya (Kalan, 2014). Oleh karena itu, proses dengan tenaga manusia terlihat sebagai upaya yang lebih efektif dengan berbagai 
resikonya. Perlengkapan yang diperlukan juga membutuhkan dana tersendiri. Hal ini yang kemudian memicu belum terpenuhinya public goods negara anggota termasuk Vietnam. Lantaran dana bantuan yang diperlukan tidak didapatkan dengan mudah.

\section{KESIMPULAN}

Berdasarkan keseluruhan uraian di atas, tulisan ini menunjukkan bahwa penyebab ARMAC belum begitu efektif di Vietnam dapat dilihat melalui interestbased theory dan juga power-based theory. Adanya common interest di awal pembentukan awal ARMAC menjadi pondasi dalam peresmian rezim tersebut. Namun seiring berjalannya waktu, lantaran adanya interest Vietnam lainnya yang masih terfokus pada isu darurat lainnya. Selain itu, kondisi perekonomian Vietnam juga menjadi salah satu faktor penyebab kurang optimalnya ARMAC bagi Vietnam. Hal ini mengakibatkan partisipasi Vietnam yang bisa dibilang tidak seaktif negara lainnya, seperti Kamboja. Selain itu, sifat rasional sebuah negara juga mendorong negara tersebut untuk bertindak sesuai tuntutan yang dihadapinya. Oleh karena itu, Vietnam belum dapat memenuhi public goods yang diharapkan dapat dipenuhi melalui ARMAC.

\section{DAFTAR PUSTAKA}

Abke, T. (2019). Southeast Asian nations increase cooperation on removing land mines. https://ipdefenseforum.com/2019/10/southeast-asian-nationsincrease-cooperation-on-removing-land-mines /

Alkadrie, J.F. \& Mooy, J. (2016). "Optimalisasi Peran ASEAN Disability Forum dan Akses Pendidikan bagi Kaum Penyandang Disabilitas". Jurnal Dinamika Global, Vol.1, No.2, pp. 58-80.

ASEAN. (2016). ASEAN to operationalise the Regional Mine Action Center. asean.org, dilihat 29/3/2019, https://asean.org/asean-tooperationalise-the-regional-mine-action-Center/

ASEAN Regional Mine Center. ARMAC's History. aseanmineaction.org, dilihat 27/5/2019, https://aseanmineaction.org/armac/armac-history/ 
Brinket, K. (2003). "The Convention Banning Anti-Personnel Mines: Applying the Lessons of Ottawa's past in Order to Meet the Challenges of Ottawa's Future". Third World Quarterly, Vol. 24, No. 5, The Future of Humanitarian Mine Action, pp. 781-793.

Brown, M. (2013). Semakin Banyak Amunisi Bekas Perang Ditemukan di Vietnam. voaindonesia.com, dilihat 28/3/2019, https://www.voaindonesia.com/a/semakin-banyak-amunisi-bekasperang-ditemukan-di-vietnam/1614525.html

Bryman, A. (2004). Social Research Method. 2nd Ed. Oxford: Oxford University Press.

Chapman, J. (2010). "The Political Economy of Landmines: View from a Minefield in North-Western Cambodia". Economic and Political Weekly, Vol. 45, No. 36, pp. 67-74.

Frost, et al. (2017). "The effect of explosive remnants of war on global public health: a systematic mixed-studies review using narrative synthesis". Lancent Public Health, Vol. 2. pp. e286-296.

Gilson, J. (2009). "Learning to Learn and Building Communities of Practice: Nongovernmental Organisations and Examples from Mine Action in Southeast Asia". Global Society, Vol. 23, No. 3, pp. 269-293.

Guillermo, G.J. (2019). Ending Echoes of War: Addressing the Issue of Land Mines and Explosive Remnants of War in Southeast Asia. https://geraldjohnguillermo. medium.com/the-silent-war-addressingthe-issue-of-land-mines-and-explosive-remnants-of-war-in-the-asean6be2070e44f1

Haggard, S., \& Simmons, B. (1987). "Theories of international regimes". International Organization, Vol. 41, No. 3, pp. 491-517.

Hasenclever et al. (1996). "Interests, Power, Knowledge: The Study of International Regimes”. Mershon International Studies Review, Vol. 40, No. 2, pp. 177-228. 
Hasenclever et.al. (2000). "Integrating of Theories of International Regime". Review of International Studies, Vol. 26, No. 1. pp. 3-33.

Heng, K. (2020). ASEAN's Challenges and the Way Forward. https://thediplomat.com /2020/08/aseans-challenges-and-the-wayforward/

International Campaign to Ban Landmines (ICBL). A History of Landmines. icbl.org, dilihat 28/3/2019, http://www.icbl.org/en-gb/problem/ahistory-of-landmines.aspx

International Campaign to Ban Landmines (ICBL). (2006). Rangkuman Eksekutif Laporan Pengawasan Ranjau Darat 2006. the-monitor.org, dilihat 28/3/2019, www.themonitor.org/media/1684353/1m_es_2006_indonesia.pdf

Kalon, J. (2014). Rats: Scratch and sniff landmine detection. bbc.com. https://www.bbc.com/future/article/20130222-scratch-and-sniffmine-detectors

Krasner, S. (1982). "Structural Causes and Regime Consequences: Regimes as Intervening Variables". International Organization, Vol. 36, No. 2, pp. 185-205.

Landmine \& Cluster Munition Monitor. (2018). Vietnam: Casualties. themonitor.org, dilihat 28/3/2019,http://www.the-monitor.org/en$\mathrm{gb} /$ reports/2018/vietnam/casualties.aspx\# ftn1

Landmine \& Cluster Munition Monitor. (2016). Cambodia: Casualties and Victim Assistance. the-monitor.org, dilihat 25/5/2019, http://themonitor.org/en-gb/reports/2016/cambodia/ casualties-and-victimassistance.aspx

Matthew and Rutherford. (2003). "The Evolutionary Dynamics of the Movement to Ban Landmines". Alternatives: Global, Local, Political, Vol. 28, No. 1, pp. 29-56. 
Pham, T.H. and Riedel, J. (2019), "Impacts of the sectoral composition of growth on poverty reductionin Vietnam", Journal of Economics and Development, Vol. 21 No. 2, pp. 85-97.

Puchala and Hopkins. (1982). "International regime: Lessons from Inductive Analysis". International Organization, Vol. 35, No. 2.

Rogers, K. \& Kuhn, H. (2017). Vietnam War left a legacy of land mines. https://www.clarion ledger.com/story/opinion/columnists/2017/09/24/vietnam-war-leftlegacy-land-mines /697383001/

Trimble and Clasper. (2001). "Anti-Personnel Mine Injury: Mechanism and Medical Management”. J R Army Med Corps, Vol. 147, pp. 73-79.

Williams, J. (1995). "Landmines: A Global Socioeconomic Crisis". Social Justice, Vol. 22, No. 4, Public Health in the 1990s: In the Shadow of Global Transformation \& Militarism, pp. 97-113.

Young, O. R. (1980). "International Regimes: Problems of Concept Formation". World Politics, Vol. 32, No. 3, pp.331-356. 